Article

\title{
Assessment of Potato Farmland Soil Nutrient Based on MDS-SQI Model in the Loess Plateau
}

\author{
Yingying Xing ${ }^{1}$, Ning Wang ${ }^{1}$, Xiaoli Niu ${ }^{2}$, Wenting Jiang ${ }^{1}$ and Xiukang Wang ${ }^{1, * *(1)}$ \\ 1 College of Life Sciences, Yan'an University, Yan'an 716000, China; xingyingying@yau.edu.cn (Y.X.); \\ wangwangning0@gmail.com (N.W.); jiangwenting@yau.edu.cn (W.J.) \\ 2 College of Agricultural Equipment Engineering, Henan University of Science and Technology, \\ Luoyang 471000, China; niuxiaoli88@haust.edu.cn \\ * Correspondence: wangxiukang@yau.edu.cn
}

Citation: Xing, Y.; Wang, N.; Niu, X.; Jiang, W.; Wang, X. Assessment of Potato Farmland Soil Nutrient Based on MDS-SQI Model in the Loess Plateau. Sustainability 2021, 13, 3957. https://doi.org/10.3390/su13073957

Academic Editor: Victor Rolo

Received: 19 February 2021

Accepted: 25 March 2021

Published: 2 April 2021

Publisher's Note: MDPI stays neutral with regard to jurisdictional claims in published maps and institutional affiliations.

Copyright: (c) 2021 by the authors. Licensee MDPI, Basel, Switzerland. This article is an open access article distributed under the terms and conditions of the Creative Commons Attribution (CC BY) license (https:// creativecommons.org/licenses/by/ $4.0 /)$.

\begin{abstract}
Soil nutrients are essential nutrients provided by soil for plant growth. Most researchers focus on the coupling effect of nutrients with potato yield and quality. There are few studies on the evaluation of soil nutrients in potato fields. The purpose of this study is to investigate the soil nutrients of potato farmland and the soil vertical nutrient distributions, and then to provide a theoretical and experimental basis for the fertilizer management practices for potatoes in Loess Plateau. Eight physical and chemical soil indexes were selected in the study area, and 810 farmland soil samples from the potato agriculture product areas were analyzed in Northern Shaanxi. The paper established the minimum data set (MDS) for the quality diagnosis of the cultivated layer for farmland by principal component analysis (PCA), respectively, and furthermore, analyzed the soil nutrient characteristics of the cultivated layer adopted soil quality index (SQI). The results showed that the MDS on soil quality diagnosis of the cultivated layer for farmland soil included such indicators as the soil organic matter content, soil available potassium content, and soil available phosphorus content. The comprehensive index value of the soil quality was between 0.064 and 0.302. The SPSS average clustering process used to classify SQI was divided into three grades: class I $(36.2 \%)$ was defined as suitable soil fertility (SQI $<0.122)$, class II $(55.6 \%)$ was defined as moderate soil fertility $(0.122<\mathrm{SQI}<0.18)$, and class III $(8.2 \%)$ was defined as poor soil fertility (SQI > 0.186). The comprehensive quality of the potato farmland soils was generally low. The proportion of soil nutrients in the SQI composition ranged from large to small as the soil available potassium content $=$ soil available phosphorus content $>$ soil organic matter content, which became the limiting factor of the soil organic matter content in this area. This study revolves around the 0 to $60 \mathrm{~cm}$ soil layer; the soil fertility decreased gradually with the soil depth, and had significant differences between the respective soil layers. In order to improve the soil nutrient accumulation and potato yield in potato farmland in northern Shaanxi, it is suggested to increase the fertilization depth (20 to $40 \mathrm{~cm}$ ) and further study the ratio of nitrogen, phosphorus, and potassium fertilizer.
\end{abstract}

Keywords: potato; minimum data sets; soil nutrient; soil fertility index

\section{Introduction}

Soil is an important natural resource, and soil nutrients are key to contributing to food security, human health, and sustainable development. Soil plays a special role in crop growth and reproduction, such as nutrient storage, nutrient transformation and circulation, rainwater conservation, biological support, stability, and as a buffer of environmental changes [1-3]. The core of soil science research is soil fertility, and soil nutrient content is an important indicator of soil fertility [4]. Soil nutrients have the characteristics of flow and migration in soil. Therefore, the analysis of the soil nutrient content and spatial distribution, the classification of soil nutrient levels and the comprehensive evaluation of soil nutrients are the most effective means to develop a scientific and reasonable fertilization program $[5,6]$. It is also the main measure to reduce the excessive application of fertilizer, 
improve the utilization efficiency of fertilizer and protect the sustainable development of the environment.

Soil nutrients play an important role in the growth of the plant and any imbalance in soil fertility affects the crop productivity as well as posing severe environmental hazards [7]. In the agricultural ecosystem, human regulation plays a dominant role, and the main source of nutrients is fertilizer application. According to statistics from 2000 to 2015, it is estimated that the quality of arable land in China is poor, and low- and medium-yield farmland occupies $72 \%$ of the total arable land area [8]. The soil degradation in the black soil region of northeast China was severe, and agricultural production capacity was lost in some areas [9]. Many researchers have carried out soil nutrient evaluation in order to ensure the soil water supply and fertilizer capacity and prevent blind fertilization [10-12]. Soil nutrient assessment is essential to the basic investigation and research of efficient agriculture [13]. Precision agriculture requires a combination of crop yield components and national policies to reasonably regulate the use and dosage of fertilizers input into the farmland ecosystem, which is conducive to meeting the production conditions of marginal effect and achieving the maximum utilization rate of fertilizers [14].

Soil nutrient assessment refers to the monitoring and evaluation of soil properties, soil functions and soil conditions. Soil quality is usually assessed through the measurement of selected soil properties. The evaluation of soil quality is difficult due to the heterogeneity of soil, and the physical, chemical, and biological properties of soil vary greatly in different regions. Thus, to comprehensively assess soil quality, a soil quality index (SQI) that integrated soil properties into an overall index was established and has been used widely. Many researchers have selected multiple soil evaluation indexes such as $\mathrm{pH}$ value, salinity, and clay weight $[15,16]$. Some researchers selected multiple soil evaluation indexes such as $\mathrm{pH}$ value, $\mathrm{C} / \mathrm{N}$, and soil nematode to establish the minimum data set of soil evaluation $[17,18]$. Some researchers used soil material indexes such as porosity and three-dimensional aggregate characteristics to evaluate farmland soil quality $[19,20]$. Some researchers selected soil quality evaluation indexes from three aspects of soil physics, chemistry, and microorganism, and established the microbial community and enzyme activity evaluation system [21,22]. Therefore, it is particularly important to select appropriate evaluation indexes scientifically, and soil indexes that mainly affect crop growth should be considered simultaneously. In addition, soil quality and soil fertility assessments have also been carried out because their selection indexes are similar to the easily confused methods of evaluation, which leads to the tendency to evaluate soil fertility in soil quality assessment.

The limiting factors of soil nutrient vary with land use modes, land types, ecosystems, locations, and soil parent materials $[23,24]$. Therefore, the selection of appropriate indexes is particularly important for the results of soil assessment. The assessment of soil quality could lead to new methods and practices that could be applied to more sustainable development. The establishment of a minimum data set (MDS) is a convenient process for selecting soil quality indicators and evaluation [25]. The MDS can reduce data redundancy by selecting the most appropriate metric among preselected metrics. In addition, the weight of selected indexes can be generated during the establishment of MDS, which reduces the subjective influence of human factors on soil quality and is conducive to subsequent soil quality evaluation [26]. Many researchers have conducted soil quality assessments based on MDS [27-29]. The MDS of soil quality indicators has been used to evaluate the relationship between the indicators and their effects on soil properties and crops [30]. There are many methods to construct the minimum data set, such as the grey correlation method, principal component analysis (PCA) method, and correlation coefficient method, etc. The PCA method has strong objectivity and can ensure the minimum loss of original data information to reflect the impact of indicators on soil quality [31]. The four indicators extracted from the MDS were significantly correlated with the fertility indicators established by all indicators [32]. The MDS can well reflect the regional differences and is suitable for soil nutrient evaluation [25]. 
The Loess Plateau is one of the most advantageous potato producing areas in China. In recent years, about $50 \%$ of the potato yield in northern Shaanxi reached the middle level, and the ratio of high potato yield was less than 6\% [33]. The land resources in the Loess Plateau were affected by unreasonable fertilization, which resulted in soil quality degradation and threatened the local ecological security [34]. Research on the soil quality of potato fields in the Loess Plateau has been relatively rare in recent years. There are two problems in previous studies. One is that many studies only use statistical data on the sample scale, and the results are not extended to the whole region. Second, most of the studies focus on regional ecosystems and do not evaluate specific land use types.

The purpose of this study was to evaluate the soil quality of potato cropland on the Loess Plateau, based on soil nutrient indicators from 2017 to 2018. This study attempts to use principal component analysis and correlation analysis to determine the MDS of soil nutrient evaluation in this region, and the fuzzy mathematics membership function method to establish a soil nutrient evaluation index. The results are useful for local potato field scientific fertilization and soil protection.

\section{Materials and Methods}

\subsection{Site Description and Soil Sampling}

The experiments were carried out in 10 counties $\left(36^{\circ} 28^{\prime}-39^{\circ} 37^{\prime} \mathrm{N}, 108^{\circ} 21^{\prime}-109^{\circ} 55^{\prime} \mathrm{E}\right.$, altitude of 762 to $1340 \mathrm{~m}$ above sea level) in the Loess Plateau region of China from 2017 to 2018 (Figure 1). The region is a typical hilly landform of the Loess Plateau and belongs to an arid and semi-arid continental monsoon climate. The climate is mild and semiarid, with an annual average temperature of $9{ }^{\circ} \mathrm{C}$, a monthly average maximum temperature of $22^{\circ} \mathrm{C}$ (July), and a monthly average minimum temperature of $-4.6^{\circ} \mathrm{C}$ (January). The average annual sunshine duration of $2200 \mathrm{~h}$ exceeds 158 days without frost and the mean annual radiation is $490 \mathrm{KJ} / \mathrm{cm}^{2}$. From 1990 to 2018 , the annual average precipitation in this region was $480 \mathrm{~mm}$. The soil type is loess soil, which is classified as Inceptisol according to the USDA soil classification and Cambisol according to the World Reference Database System [21]. The average sand (2.00 to $0.02 \mathrm{~mm}$ grain size), silt (0.02 to $0.002 \mathrm{~mm}$ ), and clay $(<0.002 \mathrm{~mm})$ contents in the 0 - to $80-\mathrm{cm}$ soil profile was measured with a laser particle size analyzer (Dandong Haoyu Technology Co., Ltd., Dandong, Liaoning, China), and the values were $62 \%, 25 \%$, and $13 \%$, respectively.

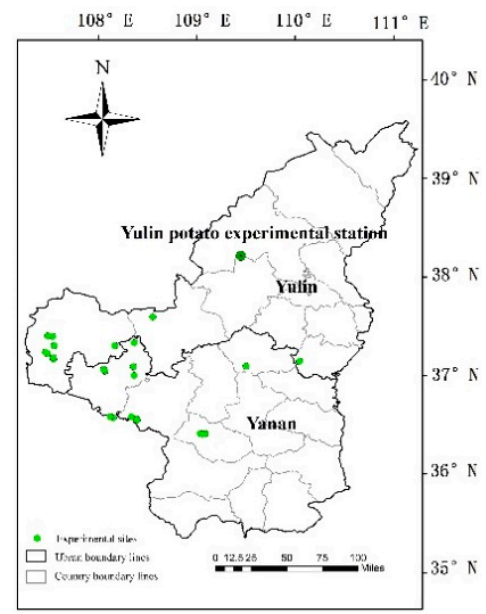

Figure 1. The map depicts the collection area of soil and plant samples on the Loess Plateau of China. These circles indicate the location of the experiment site. The thick line represents the city boundary and the thin line represents the county boundary.

\subsection{Sample Collection and Determination Methods}

Soil samples should be collected from farmland or test plots with an area greater than $600 \mathrm{~m}^{3}$. Soil cores were collected using an auger with a $25 \mathrm{~mm}$ inner diameter. Five sample 
points were randomly collected from the same test plot at $0-$ to $60-\mathrm{cm}$ soil depths. The soil temperature ranged from 12.3 to $17.4{ }^{\circ} \mathrm{C}$ when we collected the soil samples. The soil samples were air-dried, homogenized, and hand ground to pass through a 2-mm sieve for the determination of soil physical and chemical index. The soil depth from 0 to $60 \mathrm{~cm}$ was determined as S, 0 to $20 \mathrm{~cm}$ as $\mathrm{S} 1,20$ to $40 \mathrm{~cm}$ as S2, and 40 to $60 \mathrm{~cm}$ as S3.

The soil organic matter content was determined by the potassium dichromate volumetric method (external heating method) [33]. The soil available potassium was determined by the flame photometry method with $\mathrm{NH}_{4} \mathrm{OAc}$ extraction [33]. The soil available phosphorus was determined by the molybdenum antimony anti-spectrophotometry method with $\mathrm{NaHCO}_{3}$ extraction [33]. The soil acidity $(\mathrm{pH})$ was measured in an aqueous soil extract in de-ionized water (1:2.5 soil:water) [33]. For the soil electrical conductivity 1:5 soil-to-water ratio solution, $50 \mathrm{~g}$ of soil was mixed with $250 \mathrm{~g}$ of distilled water, and repeated three times, shaking manually four times every $30 \mathrm{~min}$ for $1 \mathrm{~min}$ and standing for $4 \mathrm{~h}$ to achieve balance. Once the 1:5 soil-water solutions reached equilibrium, the soil's electrical conductivity was measured by inserting an Accumet $50 \mathrm{~m}$ (Fisher Scientific, Hampton, NH, USA) into the solution [35]. The content of soil alkali-hydrolyzable nitrogen was determined by conductance titration; $0.5 \mathrm{~g}$ soil samples were distilled with $2 \mathrm{~mol} \mathrm{~L}^{-1} \mathrm{NaOH}$ for $5 \mathrm{~h}$, then treated with $10 \mathrm{~mol} \mathrm{~L}^{-1} \mathrm{NaOH}$ for 7 min, and then treated with $40 \mathrm{~g} \mathrm{~L}^{-1}$ boric acid for $\mathrm{NH}_{3}$, which was absorbed and released by direct steam [36]. The soil water content was determined using the gravimetric method. The soil nitrate $\mathrm{N}$ content was measured using a spectrophotometer (UV-2600, Shanghai Hengping Scientific Instrument Co. Ltd., Shanghai, China). First, $0.5 \mathrm{~g}$ of fresh soil was transferred to a 100-mL Erlenmeyer flask, and then $50 \mathrm{~mL}$ of a $2-\mathrm{mol} \mathrm{L}^{-1}$ potassium chloride solution was added to the Erlenmeyer flask. Next, the mixture was oscillated for 30 min using a shock machine until reaching uniformity. Finally, the solution was filtered, and then $5 \mathrm{~mL}$ of the solution was measured using a spectrophotometer at a wavelength of $210 \mathrm{~nm}$ [10].

\subsection{Establishment of Minimum Data Set MDS}

What comes first is to screen soil nutrient indicators, in order to avoid the influence of redundant data and complex multiple correlations of indicators on the constructed soil quality assessment index. Principal component analysis (PCA) was used to reduce dimensionality and representative soil measurement indexes were selected to establish MDS. When performing the principal component analysis, the extract principal components had eigenvalues greater than 1 . The index with the same principal component load $\geqq 0.5$ is divided into one group. If the load of a soil parameter in two principal components is higher than 0.5 at the same time, the parameter should be merged into the group with a lower correlation with other parameters.

Second, to solve the vector normal, the vector normal of the evaluation index was calculated. The vector normal is the length of the vector normal mode of the index in a multi-dimensional space composed of components. The longer the length, the greater the comprehensive load of the indicator in all principal components, and the greater its ability to interpret comprehensive information. The vector normal is calculated as follows:

$$
\mathrm{N}_{\mathrm{ik}}=\sqrt{\sum_{\mathrm{i}=1}^{\mathrm{k}}\left(\mathrm{u}_{\mathrm{ik}}^{2} \cdot \lambda_{\mathrm{k}}\right)}
$$

In the formula, $\mathrm{N}_{\mathrm{ik}}$ is the comprehensive load of the $\mathrm{i}$-th index on the first $\mathrm{k}$ principal components of the eigenvalue; $u_{i k}$ is the load of the $i$-th index on the $k$-th principal component; $\lambda_{\mathrm{k}}$ is the eigenvalue of the $\mathrm{k}$-th principal component. 


\subsection{Establishment of Soil Nutrient Evaluation Index}

To calculate the soil quality index (SQL) for different data sets [37-39], the calculation formula is as follows:

$$
\mathrm{SQL}=\sum_{\mathrm{i}=1}^{\mathrm{k}} \mathrm{W}_{\mathrm{i}} \cdot \mathrm{N}_{\mathrm{i}}
$$

In the formula, SQI is the soil nutrient evaluation index; $\mathrm{W}_{\mathrm{i}}$ is the weight of the $\mathrm{i}$-th index; $\mathrm{N}_{\mathrm{i}}$ is the membership of the $\mathrm{i}$-th index. The weight calculation formula is as follows:

$$
\begin{gathered}
\mathrm{W}_{\mathrm{i}}=\frac{\mathrm{M}_{\mathrm{i}}}{\sum \mathrm{M}_{\mathrm{i}}} \\
\mathrm{M}_{\mathrm{i}}=\frac{\sum_{\mathrm{i}=1}^{\mathrm{k}}\left(\frac{\mathrm{u}_{\mathrm{ik}}}{\left.\sqrt{\lambda_{\mathrm{k}}} \cdot \theta_{\mathrm{ik}}\right)}\right.}{\sum_{\mathrm{i}=1}^{\mathrm{k}} \theta_{\mathrm{ik}}}
\end{gathered}
$$

In the formula, $\mathrm{W}_{\mathrm{i}}$ is the weight of the $\mathrm{i}$-th index; $\theta_{\mathrm{ik}}$ is the variance percentage of the $i$-th index on the k-th principal component. The membership degree rising function $f(x)$ calculation formula is as follows:

$$
f(x)=\left\{\begin{array}{c}
1.0 x>x_{2} \\
\frac{0.9\left(x-x_{1}\right)}{\left(x_{2}+x_{1}\right)}+0.1 x_{1}<x \leq x_{2} \\
0.1 x<x_{1}
\end{array}\right.
$$

In the formula, $x_{1}$ is the minimum value of the soil index threshold; $x_{2}$ is the maximum value of the soil index threshold.

\subsection{Data Processing Methods}

SPSS 22.0 statistical software and Sigma Plot 14.0 were used for statistical analysis and data plotting, respectively. Tukey's multiple comparison test was used to detect differences among treatments at the 0.05 significance level. In addition, the relationships among all the parameters (soil nutrient content) were calculated using a bivariate correlation analysis (Pearson correlation coefficient and double-tailed significance test).

\section{Results and Analysis}

\subsection{Soil Physical and Chemical Properties}

The soil organic matter content in soil layer $\mathrm{S} 1$ was significantly different from that in soil layer S2 and S3, but there was no significant difference between S2 and S3 (Figure 2A). The organic matter content in the soil layer $\mathrm{S} 1$ was up to $8.4 \mathrm{~g} \mathrm{~kg}^{-1}$ on average, which was $30 \%$ and $40.7 \%$ higher than that in higher than that in S2 and S3, respectively. The available potassium content in soil layer S1 was significantly different from that in soil layer S2 and S3, but there was no significant difference between S2 and S3 (Figure 2B). The available potassium content in soil layer S1 was the highest at $69.1 \mathrm{mg} \mathrm{kg}^{-1}$ on average, which was $19.7 \%$ higher than that in S2 and 26\% higher than that in S3. The soil available phosphorus content in soil layer S1 was significantly different from that in soil layer S2 and S3, but there was no significant difference between S2 and S3 (Figure 2C). As the depth of the soil layer decreased, the available phosphorus content showed a decreasing trend. The soil available phosphorus content in soil layer S1 was the highest at $16.9 \mathrm{mg} \mathrm{kg}^{-1}$ on average, which was $49.3 \%$ and $58.7 \%$ higher than that in S2 and S3, respectively. The soil pH in S1 soil layer is significantly different from S2 and S3 (Figure 2D). As the depth of the soil layer decreased, the $\mathrm{pH}$ value increased. The average soil $\mathrm{pH}$ value of the $\mathrm{S} 3$ soil layer was 8.6, which was $1.9 \%$ and $0.3 \%$ higher than that in $\mathrm{S} 1$ and S2, respectively. 

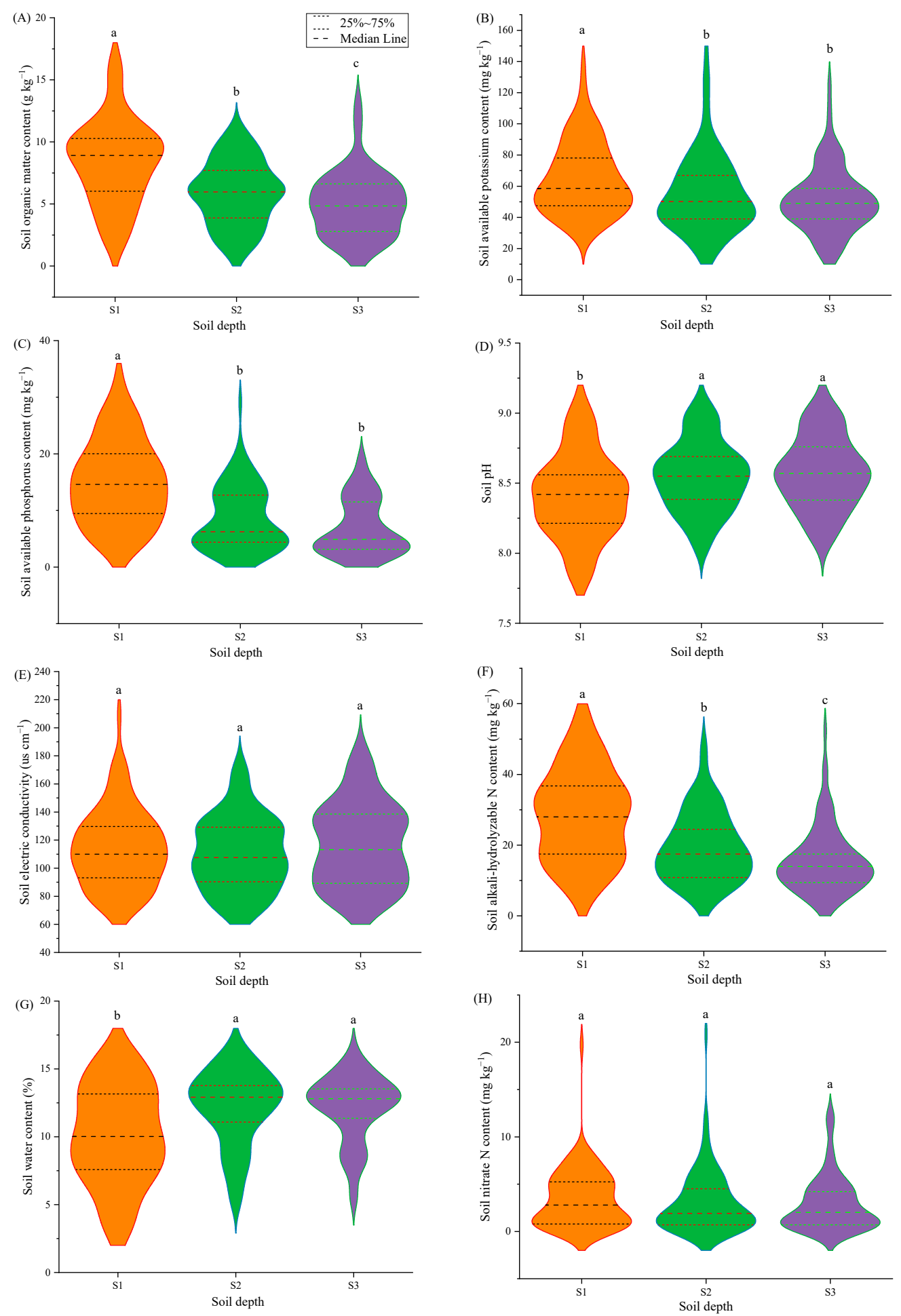

Figure 2. The relationship between soil depth and soil organic matter content (A), soil available potassium content (B), soil available phosphorus content (C), soil pH (D), soil electric conductivity (E), soil alkaline hydrolyzable $\mathrm{N}$ content (F), soil water content $(\mathbf{G})$, and soil nitrate $\mathrm{N}$ content $(\mathbf{H}) .0$ to $20 \mathrm{~cm}$ was determined as S1, 20 to $40 \mathrm{~cm}$ was determined as S2, and 40 to $60 \mathrm{~cm}$ was determined as S3. The different letters indicate significant differences at $p<0.05$.

There is no significant difference in the electrical conductivity among soil layers (Figure 2E). The soil alkaline hydrolyzable N content in soil layer S1 was significantly different from that in soil layer S2 and S3, and the difference between S2 and S3 was significant (Figure 2F). The soil alkali-hydrolyzable $\mathrm{N}$ content decreased with the decrease 
of soil depth. The soil alkali-hydrolyzable $\mathrm{N}$ content in soil layer S1 was the highest at $28.5 \mathrm{mg} \mathrm{kg}^{-1}$ on average, which was $32 \%$ and $45.2 \%$ higher than that in S2 and S3, respectively. The soil water content in soil layer S1 was significantly different from that in soil layer S2 and S3 (Figure 2G). The soil water content of soil layer S2 (12.18\%) and S3 $(12.14 \%)$ was higher on average, which was $14.4 \%$ and $19.1 \%$ higher than that of S1. There was no significant difference in the soil nitrate nitrogen content between the soil layers (Figure $2 \mathrm{H}$ ).

\subsection{The Establishment of the Minimum Data Set MDS}

Based on the results of principal component analysis (Table 1), the eigenvalues of the first three principal components are greater than 1, and the cumulative contribution rate of the three principal components is $64 \%$.

Table 1. Eigenvalue and contribution rate in principal components analysis.

\begin{tabular}{ccccccc}
\hline \multirow{2}{*}{ Component } & \multicolumn{3}{c}{ Initial Eigenvalues } & \multicolumn{2}{c}{ Extract the Sum of Squares and Load It } \\
\cline { 2 - 7 } & Total & $\begin{array}{c}\text { Variance } \\
\mathbf{( \% )}\end{array}$ & $\begin{array}{c}\text { Accumulation } \\
\mathbf{( \% )}\end{array}$ & Total & $\begin{array}{c}\text { Variance } \\
\mathbf{( \% )}\end{array}$ & $\begin{array}{c}\text { Accumulation } \\
\mathbf{( \% )}\end{array}$ \\
\hline 1 & 2.386 & 29.825 & 29.825 & 2.386 & 29.825 & 29.825 \\
2 & 1.591 & 19.89 & 49.715 & 1.591 & 19.89 & 49.715 \\
3 & 1.142 & 14.269 & 63.984 & 1.142 & 14.269 & 63.984 \\
\hline
\end{tabular}

According to the principal component analysis load matrix (Table 2) and the screening criteria, the final soil organic matter content, soil $\mathrm{pH}$ value, soil electric conductivity, and soil alkaline hydrolyzable $\mathrm{N}$ content entered PC1, thesoil available potassium content and soil nitrate $\mathrm{N}$ content entered PC2, and soil available phosphorus content and soil water content entered PC3.

Table 2. Principal component loading matrix and calculated vector normal.

\begin{tabular}{ccccc}
\hline \multirow{2}{*}{ Indicator } & \multicolumn{3}{c}{ Principal Component } & \multirow{2}{*}{ Vector Normal } \\
\cline { 2 - 4 } & PC1 & PC2 & PC3 & \\
\hline SOM & 0.854 & 0.067 & -0.069 & 1.324 \\
K & 0.362 & 0.673 & -0.161 & 1.031 \\
P & 0.480 & -0.021 & 0.685 & 1.042 \\
pH & -0.556 & 0.492 & 0.226 & 1.087 \\
EC & 0.532 & -0.292 & -0.015 & 0.901 \\
SAN & 0.811 & 0.118 & 0.096 & 1.266 \\
SWC & 0.191 & 0.546 & -0.602 & 0.988 \\
SNN & -0.088 & 0.703 & 0.468 & 1.027 \\
\hline
\end{tabular}

Note: SOM, soil organic matter content; K, soil available potassium content; $\mathrm{P}$, soil available phosphorus content, EC, soil electric conductivity; SAN, soil alkaline hydrolyzable N content; SWC, soil water content; SNN, soil nitrate $\mathrm{N}$ content.

The vector normal of each indicator is shown in Table 2, and selects the indicator whose vector normal is in the range of $10 \%$ of the highest total score in each group. The indicators entering MDS are the soil organic matter content, soil available potassium content, and soil available phosphorus content. Correlation tests between soil indicators were used to screen MDS indicators. Highly correlated indicators with the highest vector normal entered the smallest data set. Low correlations entered the same group of indicators into the MDS. It can be known from the Table 3 that the MDS index has a significant correlation with each soil nutrient index $(p<0.05)$, which satisfies the comprehensive evaluation of nutrients instead of all soil indicators. Therefore, the indicators that finally entered MDS were the soil organic matter content, soil available potassium content and soil available phosphorus content. 
Table 3. Correlation coefficient between matrix among soil fertility indicators.

\begin{tabular}{ccccccccc}
\hline Indicators & SOM & K & $\mathbf{P}$ & $\mathbf{p H}$ & $\mathbf{E C}$ & SAN & SWC & SNN \\
\hline SOM & 1 & & & & & & & \\
K & $0.322^{* *}$ & 1 & & & & & & \\
P & $0.278^{* *}$ & 0.069 & 1 & & & & & \\
pH & $-0.355^{* *}$ & 0.034 & $-0.178^{* *}$ & 1 & & & & \\
EC & $0.403^{* *}$ & -0.06 & $0.112^{* *}$ & $-0.210^{* *}$ & 1 & & & \\
SAN & $0.601^{* *}$ & $0.254^{* *}$ & $0.346^{* *}$ & $-0.312^{* *}$ & $0.292^{* *}$ & 1 & & \\
SWC & $0.158^{*}$ & $0.300^{* *}$ & $-0.139^{*}$ & 0.014 & -0.018 & $0.142^{*}$ & 1 & \\
SNN & -0.051 & $0.213^{* *}$ & 0.111 & $0.365^{* *}$ & -0.111 & 0.039 & 0.112 & 1 \\
\hline
\end{tabular}

Note: ** Significant correlation at level 0.01 (both sides); * Significant correlation at level 0.05 (both sides); SOM, soil organic matter content; $\mathrm{K}$, soil available potassium content; $\mathrm{P}$, soil available phosphorus content; EC, soil electric conductivity; SAN, soil alkaline hydrolyzable N content; SWC, soil water content; SNN, soil nitrate $\mathrm{N}$ content.

\subsection{Comprehensive Evaluation of Nutrients}

According to the results of the principal component analysis, the weight of the soil nutrient index of MDS was calculated, and the results were shown in Table 4 . The weights of soil indexes mainly included soil organic matter (0.176), soil available potassium (0.164), and soil available phosphorus (0.192). The soil organic matter, available potassium and available phosphorus in this survey all had a positive effect on the growth of potato, which belonged to the ascending membership function. The turning point value of the function curve and the determination of index membership are shown in Table 4.

Table 4. Communality and weight of soil quality indicators in the MDS.

\begin{tabular}{|c|c|c|c|c|c|}
\hline \multirow{2}{*}{ MDS } & \multirow{2}{*}{$\begin{array}{c}\text { Common Factor } \\
\text { Variance }\end{array}$} & \multirow{2}{*}{ Weightiness } & \multicolumn{2}{|c|}{ Turning Point } & \multirow{2}{*}{$\begin{array}{l}\text { Membership } \\
\text { Function }\end{array}$} \\
\hline & & & $X_{1}$ & $X_{2}$ & \\
\hline SOM & 0.260 & 0.176 & 6 & 40 & \multirow{3}{*}{$\begin{array}{l}\text { Distribution curve of } \\
\text { upper ring type }\end{array}$} \\
\hline $\mathrm{K}$ & 0.242 & 0.164 & 20 & 200 & \\
\hline $\mathrm{P}$ & 0.283 & 0.192 & 3 & 40 & \\
\hline
\end{tabular}

Note: SOM, soil organic matter content; K, soil available potassium content; $\mathrm{P}$, soil available phosphorus content.

The soil quality evaluation index (SQI) is shown in Table 5. The SQI of this study ranged from 0.064 to 0.302 , which was classified as Grade I (SQI < 0.122), Grade II $(0.122<\mathrm{SQI}<0.186)$, and Grade III (SQI > 0.186). In this study, the soil nutrient evaluation index showed moderate variation, among which SQI was $8.2 \%$ of Grade III, $55.6 \%$ of Grade II, and $36.2 \%$ of Grade I. As the depth of the soil layer decreases, the SQI shows a downward trend, and the SQI varies significantly between layers. Grade I of SQI in S1 is relatively high, while Grade II is the lowest. The proportion of Grade II in SQI of S2 layer and S3 layer is relatively high, while that of Grade III is relatively low, showing that the proportion of Grade I and II tends to be stable, and the proportion of Grade III tends to 0 .

Table 5. Classification of scores for comprehensive evaluation of soil nutrients.

\begin{tabular}{|c|c|c|c|c|c|c|c|}
\hline \multirow{3}{*}{ Soil depth } & \multirow{3}{*}{$\begin{array}{c}\text { SQI } \\
\text { Rangeability }\end{array}$} & \multirow{3}{*}{ SQI Mean } & \multirow{3}{*}{$\begin{array}{c}\text { SQI } \\
\text { Standard } \\
\text { Deviation }\end{array}$} & \multirow{3}{*}{$\begin{array}{c}\text { SQI } \\
\text { Coefficient } \\
\text { of Variation }\end{array}$} & \multicolumn{3}{|c|}{ The Proportion of Different Soil Fertility } \\
\hline & & & & & I & II & III \\
\hline & & & & & SQI $<0.122$ & $0.122<\mathrm{SQI}<0.186$ & $\mathrm{SQI}>\mathbf{0 . 1 8 6}$ \\
\hline $\mathrm{S}$ & $0.064-0.302$ & 0.125 & 0.043 & $34.8 \%$ & 0.362 & 0.556 & 0.082 \\
\hline S1 & $0.083-0.281$ & $0.160 \mathrm{a}$ & 0.045 & $27.9 \%$ & 0.605 & 0.173 & 0.222 \\
\hline $\mathrm{S} 2$ & $0.069-0.302$ & $0.113 \mathrm{~b}$ & 0.034 & $30.0 \%$ & 0.259 & 0.716 & 0.025 \\
\hline S3 & $0.064-0.161$ & $0.101 \mathrm{c}$ & 0.025 & $24.8 \%$ & 0.222 & 0.778 & 0.000 \\
\hline
\end{tabular}

Note: Significant differences in lowercase letters $(p<0.05)$. 


\subsection{Evaluation of Nutrients in Different Soil Layers}

The cumulative value of the soil nutrient quality evaluation index based on the composition of organic matter, available potassium and available phosphorus is shown in Figure 3. The soil nutrient quality evaluation index is a large proportion of medium-speed potassium and fast-effect phosphorus, and the minimum of organic matter is the main problem of soil nutrient in the area.

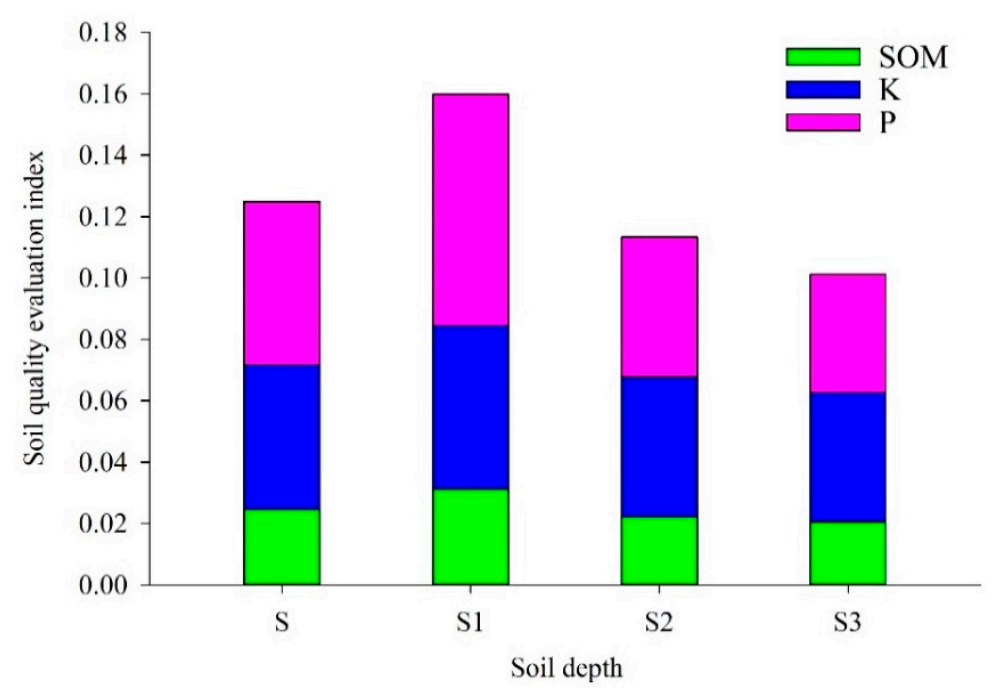

Figure 3. Cumulative histogram of soil quality comprehensive index.

With the increase of soil depth, the proportion of organic matter, available potassium and available phosphorus in the evaluation index all decreased. The proportion of soil available phosphorus in layer S1 is the largest, and the proportion of soil available potassium and phosphorus in layer S2 and layer S3 is similar.

\section{Discussion}

Many researchers use quantitative evaluation and mathematical models to study soil nutrients [40-42]. In this study, principal component analysis was used to screen eight soil indicators, and finally soil organic matter, available potassium and available phosphorus and nitrogen were determined as MDS. The cumulative contribution rate of soil indicators in the MDS constructed in this study was $63.98 \%$, and correlation analysis showed that each soil index was significantly correlated with the construction of MDS soil indicators. Soil organic matter, soil available potassium, soil available phosphorus and soil nitrate nitrogen play an important role in constructing the MDS of soil nutrient evaluation [43]. Different factors are selected to participate in the evaluation of soil quality, leading to slightly different key factors in the final evaluation. The soil quality evaluation is sufficient to study specific land functions and land use types.

The SQI range of this survey is 0.064 to 0.302 , which is divided into three levels, namely Grade I (SQI < 0.122), Grade II $(0.122<$ SQI < 0.186), and Grade III (SQI > 0.186). The soil nutrient quality evaluation index of $91.8 \%$ in the Loess Plateau was in grade I and grade II, and the soil nutrient evaluation index was poor overall. Some studies have also shown that the Loess Plateau belongs to low quality cultivated land, with large topographic fluctuation, a lack of irrigation conditions, poor soil quality and low soil nutrient content $[44,45]$. The scope of this study was 0 to $60 \mathrm{~cm}$ soil layer, and the SQI showed a downward trend as the soil layer decreased, and there were significant differences in the SQI among different layers. This is similar to the distribution of soil nutrients in farmland by many researchers $[46,47]$. The proportion of SQI of topsoil S1 in each grade ranged from large to small as Grade I > Grade II > Grade III; SQI varies with the change of region and the range of change is large in this study. 
Continuous fertilizer application resulted in the enrichment of soil nutrients in the topsoil, but the soil nutrients were lost due to ammonia volatilization, runoff and leaching, etc., resulting in a great change in the content of soil nutrients in the topsoil [48-50]. The SQI of middle soil S2 and lower soil S3 was higher in Grade II and lower in Grade III. With the advance of the growth period, soil nutrients slowly migrate downward, and the amount of nutrients taken away by crops in the middle and lower soils gradually increases, resulting in the decrease of nutrient content in the middle and lower soils. The same study showed that the soil nutrient content in the 0 to $40 \mathrm{~cm}$ soil layer of sloping farmland on the Loess Plateau was the highest, and the nutrient content decreased with the increase of profile depth [51].

In the composition of soil nutrient quality index in this study, soil nitrate nitrogen and soil available potassium accounted for a large proportion, while soil organic matter accounted for the smallest proportion, indicating that soil organic matter became the limiting factor of soil nutrient quality in this region. In the past 20 years, soil nutrient observation data in the Loess Plateau region showed that organic matter content was still in a deficient state [52]. Soil organic matter plays an important role in providing nutrients and improving soil fertility. The results showed that the long-term application of organic fertilizer significantly increased the content of soil organic carbon, and the combined application of nitrogen and phosphate fertilizer increased the content of soil available nutrients [53]. Therefore, it is suggested to increase the input of organic matter in this area for a long time to improve and enhance soil fertility.

The reasons for the poor soil nutrient quality are poor soil physical and chemical properties, low input or large nutrient loss. This area is an ecologically fragile area, and concentrated rainfall leads to the coexistence of soil and water loss and nutrient loss. A large number of investigations showed that the traditional fertilization situation in this area was the insufficient application of organic fertilizer, excessive and insufficient input of nitrogen and phosphorus fertilizer, and less applications of potassium fertilizer. This study shows that the soil nutrients in this region are in a state of scarcity, so fertilization measures should be formulated to enhance the soil nutrient content in this region and prevent serious soil degradation caused by planting. The results show that the adjustment of the fertilization depth in Loess Plateau is beneficial to improve the utilization efficiency of fertilizer [54]. In order to improve the effective accumulation of soil nutrients in potato fields, it is suggested to apply deep fertilizer, increase the input of organic fertilizer and reasonable N-P-K application in this area.

\section{Conclusions}

In this study, the MDS evaluation indexes of soil nutrients in northern Shaanxi were soil organic matter, soil available potassium and soil available phosphorus. The SQI value range was 0.0638 to 0.469 , and the overall soil nutrient evaluation index is poor. The proportion of soil nutrient indicators in the SQI was in the order of soil available K = soil available P > soil organic matter, and organic matter has become the limiting factor for soil nutrients in the region. In order to ensure the soil nutrient accumulation and sustainable agricultural development of potato farmland in the Loess Plateau, it is suggested to increase the fertilization depth, especially the potato root layer depth $(20$ to $40 \mathrm{~cm})$, and further study is needed to determine the optimal ratio of nitrogen, phosphorus and potassium fertilizer.

Author Contributions: Y.X., N.W. and X.N. wrote the paper, X.W. designed the study idea and applied the model to calculated, Y.X., N.W., X.N. and W.J. collected and arranged the whole database, Y.X. and X.W. analyzed and discussed. All the authors revised the manuscript. All authors have read and agreed to the published version of the manuscript.

Funding: This research was funded the National Natural Science Foundation $(51669034,51809224)$ and Key Scientific Research Program of Education Department of Shaanxi Province (18JS117). The APC was funded by the National Natural Science Foundation (51809224).

Institutional Review Board Statement: Not applicable. 
Informed Consent Statement: Not applicable.

Data Availability Statement: The data presented in this study are available on request from the corresponding author.

Acknowledgments: We thank Jia Yun, Huihui Zhang, Tao Guo and Tianmei Li for providing us with experimental field plots and helping us to collect the data.

Conflicts of Interest: The authors declare no conflict of interest.

\section{References}

1. Cowie, A.L.; Penman, T.D.; Gorissen, L.; Winslow, M.D.; Lehmann, J.; Tyrrell, T.D.; Twomlow, S.; Wilkes, A.; Lal, R.; Jones, J.W.; et al. Towards sustainable land management in the drylands: Scientific connections in monitoring and assessing dryland degradation, climate change and biodiversity. Land Degrad. Dev. 2011, 22, 248-260. [CrossRef]

2. Mucina, L.; Wardell-Johnson, G.W. Landscape age and soil fertility, climatic stability, and fire regime predictability: Beyond the OCBIL framework. Plant Soil 2011, 341, 1-23. [CrossRef]

3. Panigrahi, P.; Srivastava, A.K.; Panda, D.K.; Huchche, A.D. Rainwater, soil and nutrients conservation for improving productivity of citrus orchards in a drought prone region. Agric. Water Manag. 2017, 185, 65-77. [CrossRef]

4. Yageta, Y.; Osbahr, H.; Morimoto, Y.; Clark, J. Comparing farmers' qualitative evaluation of soil fertility with quantitative soil fertility indicators in Kitui County, Kenya. Geoderma 2019, 344, 153-163. [CrossRef]

5. Hengl, T.; Leenaars, J.G.B.; Shepherd, K.D.; Walsh, M.G.; Heuvelink, G.B.M.; Mamo, T.; Tilahun, H.; Berkhout, E.; Cooper, M.; Fegraus, E.; et al. Soil nutrient maps of Sub-Saharan Africa: Assessment of soil nutrient content at $250 \mathrm{~m}$ spatial resolution using machine learning. Nutr. Cycl. Agroecosyst. 2017, 109, 77-102. [CrossRef]

6. Zhao, Z.; Liu, G.; Liu, Q.; Huang, C.; Li, H.; Wu, C. Distribution characteristics and seasonal variation of soil nutrients in the Mun River Basin, Thailand. Int. J. Environ. Res. Public Health 2018, 15, 1818. [CrossRef]

7. Wang, X.; Fan, J.; Xing, Y.; Xu, G.; Wang, H.; Deng, J.; Wang, Y.; Zhang, F.; Li, P.; Li, Z. Chapter three-The effects of mulch and nitrogen fertilizer on the soil environment of crop plants. In Advances Agronomy; Sparks, D.L., Ed.; Academic Press: Cambridge, MA, USA, 2019; Volume 153, pp. 121-173.

8. Wang, X. Consumption of cropland with high yield and low irrigation water intensity by urban expansion in China during 2000-2015. Ecol. Indic. 2020, 117, 106644. [CrossRef]

9. Gong, H.; Meng, D.; Li, X.; Zhu, F. Soil degradation and food security coupled with global climate change in northeastern China. Chin. Geogr. Sci. 2013, 23, 562-573. [CrossRef]

10. Wang, X.; Guo, T.; Wang, Y.; Xing, Y.; Wang, Y.; He, X. Exploring the optimization of water and fertilizer management practices for potato production in the sandy loam soils of Northwest China based on PCA. Agric. Water Manag. 2020, 237, 106180. [CrossRef]

11. Wang, H.; Wang, X.; Bi, L.; Wang, Y.; Fan, J.; Zhang, F.; Hou, X.; Cheng, M.; Hu, W.; Wu, L.; et al. Multi-objective optimization of water and fertilizer management for potato production in sandy areas of northern China based on TOPSIS. Field Crops Res. 2019, 240, 55-68. [CrossRef]

12. Grant, C.A.; Peterson, G.A.; Campbell, C.A. Nutrient considerations for diversified cropping systems in the Northern Great Plains. Agron. J. 2002, 94, 186-198. [CrossRef]

13. Techen, A.-K.; Helming, K.; Brüggemann, N.; Veldkamp, E.; Reinhold-Hurek, B.; Lorenz, M.; Bartke, S.; Heinrich, U.; Amelung, W.; Augustin, K.; et al. Chapter Four-Soil research challenges in response to emerging agricultural soil management practices. In Advances in Agronomy; Sparks, D.L., Ed.; Academic Press: Cambridge, MA, USA, 2020; Volume 161, pp. $179-240$.

14. Van Evert, F.K.; Gaitán-Cremaschi, D.; Fountas, S.; Kempenaar, C. Can precision agriculture increase the profitability and sustainability of the production of potatoes and olives? Sustainability 2017, 9, 1863. [CrossRef]

15. Wang, F.; Yang, S.; Wei, Y.; Shi, Q.; Ding, J. Characterizing soil salinity at multiple depth using electromagnetic induction and remote sensing data with random forests: A case study in Tarim River Basin of southern Xinjiang, China. Sci. Total Environ. 2021, 754, 142030. [CrossRef] [PubMed]

16. Wu, C.; Liu, G.; Huang, C.; Liu, Q. Soil quality assessment in Yellow River Delta: Establishing a minimum data set and fuzzy logic model. Geoderma 2019, 334, 82-89. [CrossRef]

17. Obriot, F.; Stauffer, M.; Goubard, Y.; Cheviron, N.; Peres, G.; Eden, M.; Revallier, A.; Vieublé-Gonod, L.; Houot, S. Multi-criteria indices to evaluate the effects of repeated organic amendment applications on soil and crop quality. Agric. Ecosyst. Environ. 2016, 232, 165-178. [CrossRef]

18. Paz-Ferreiro, J.; Fu, S. Biological indices for soil quality evaluation: Perspectives and limitations. Land Degrad. Dev. 2016, 27, 14-25. [CrossRef]

19. Feng, Y.; Wang, J.; Liu, T.; Bai, Z.; Reading, L. Using computed tomography images to characterize the effects of soil compaction resulting from large machinery on three-dimensional pore characteristics in an opencast coal mine dump. J. Soils Sediments 2019, 19, 1467-1478. [CrossRef]

20. Behrends Kraemer, F.; Soria, M.A.; Castiglioni, M.G.; Duval, M.; Galantini, J.; Morrás, H. Morpho-structural evaluation of various soils subjected to different use intensity under no-tillage. Soil Tillage Res. 2017, 169, 124-137. [CrossRef] 
21. Qu, Q.; Xu, H.; Xue, S.; Liu, G. Stratification ratio of rhizosphere soil microbial index as an indicator of soil microbial activity over conversion of cropland to forest. Catena 2020, 195, 104761. [CrossRef]

22. Zungu, N.S.; Egbewale, S.O.; Olaniran, A.O.; Pérez-Fernández, M.; Magadlela, A. Soil nutrition, microbial composition and associated soil enzyme activities in KwaZulu-Natal grasslands and savannah ecosystems soils. Appl. Soil Ecol. 2020, 155, 103663. [CrossRef]

23. Lisetskii, F.; Stolba, V.F.; Marinina, O. Indicators of agricultural soil genesis under varying conditions of land use, Steppe Crimea. Geoderma 2015, 239-240, 304-316. [CrossRef]

24. Carter, M.R. Soil quality for sustainable land management. Agron. J. 2002, 94, 38-47. [CrossRef]

25. Li, X.; Li, H.; Yang, L.; Ren, Y. Assessment of soil quality of croplands in the corn belt of Northeast China. Sustainability 2018, 10, 248. [CrossRef]

26. Mahajan, G.; Das, B.; Morajkar, S.; Desai, A.; Murgaokar, D.; Kulkarni, R.; Sale, R.; Patel, K. Soil quality assessment of coastal salt-affected acid soils of India. Environ. Sci. Pollut. Res. 2020, 27, 26221-26238. [CrossRef]

27. Choudhury, B.U.; Mandal, S. Indexing soil properties through constructing minimum datasets for soil quality assessment of surface and profile soils of intermontane valley (Barak, North East India). Ecol. Indic. 2021, 123, 107369. [CrossRef]

28. Wang, D.; Bai, J.; Wang, W.; Zhang, G.; Cui, B.; Liu, X.; Li, X. Comprehensive assessment of soil quality for different wetlands in a Chinese delta. Land Degrad. Dev. 2018, 29, 3783-3794. [CrossRef]

29. Karaca, S.; Dengiz, O.; Demirağ Turan, İ.; Özkan, B.; Dedeoğlu, M.; Gülser, F.; Sargin, B.; Demirkaya, S.; Ay, A. An assessment of pasture soils quality based on multi-indicator weighting approaches in semi-arid ecosystem. Ecol. Indic. 2021, 121, 107001. [CrossRef]

30. Armenise, E.; Redmile-Gordon, M.; Stellacci, A.; Ciccarese, A.; Rubino, P. Developing a soil quality index to compare soil fitness for agricultural use under different managements in the Mediterranean environment. Soil Tillage Res. 2013, 130, 91-98. [CrossRef]

31. Yuan, P.; Wang, J.; Li, C.; Xiao, Q.; Liu, Q.; Sun, Z.; Wang, J.; Cao, C. Soil quality indicators of integrated rice-crayfish farming in the Jianghan Plain, China using a minimum data set. Soil Tillage Res. 2020, 204, 104732. [CrossRef]

32. Andrews, S.S.; Karlen, D.L.; Cambardella, C.A. The soil management assessment framework. Soil Sci. Soc. Am. J. 2004, 68, 1945-1962. [CrossRef]

33. Wang, N.; Xing, Y.; Wang, X. Exploring options for improving potato productivity through reducing crop yield gap in Loess Plateau of China based on grey correlation analysis. Sustainability 2019, 11, 5621. [CrossRef]

34. Li, W.; Wang, D.; Liu, S.; Zhu, Y.; Yan, Z. Reclamation of cultivated land reserves in Northeast China: Indigenous ecological insecurity underlying national food security. Int. J. Environ. Res. Public Health 2020, 17, 1211. [CrossRef]

35. Sukweenadhi, J.; Balusamy, S.R.; Kim, Y.J.; Lee, C.H.; Kim, Y.J.; Koh, S.C.; Yang, D.C. A growth-promoting bacteria, Paenibacillus yonginensis $\mathrm{DCY} 84^{\mathrm{T}}$ enhanced salt stress tolerance by activating defense-related systems in Panax ginseng. Front. Plant Sci. 2018, 9, 813. [CrossRef]

36. Bremner, J. Determination of nitrogen in soil by the Kjeldahl method. J. Agric. Sci. 1960, 55, 11-33. [CrossRef]

37. Raiesi, F. A minimum data set and soil quality index to quantify the effect of land use conversion on soil quality and degradation in native rangelands of upland arid and semiarid regions. Ecol. Indic. 2017, 75, 307-320. [CrossRef]

38. Vasu, D.; Tiwari, G.; Sahoo, S.; Dash, B.; Jangir, A.; Sharma, R.P.; Naitam, R.; Tiwary, P.; Karthikeyan, K.; Chandran, P. A minimum data set of soil morphological properties for quantifying soil quality in coastal agroecosystems. Catena 2020, 198, 105042 [CrossRef]

39. Yu, P.; Liu, S.; Zhang, L.; Li, Q.; Zhou, D. Selecting the minimum data set and quantitative soil quality indexing of alkaline soils under different land uses in northeastern China. Sci. Total Environ. 2018, 616, 564-571. [CrossRef] [PubMed]

40. Kwiatkowska-Malina, J. Qualitative and quantitative soil organic matter estimation for sustainable soil management. J. Soils Sediments 2018, 18, 2801-2812. [CrossRef]

41. Abdel-Fattah, M.K.; Mohamed, E.S.; Wagdi, E.M.; Shahin, S.A.; Aldosari, A.A.; Lasaponara, R.; Alnaimy, M.A. Quantitative evaluation of soil quality using Principal Component Analysis: The case study of El-Fayoum depression Egypt. Sustainability 2021, 13, 1824. [CrossRef]

42. Wang, Z.; Wang, G.; Zhang, Y.; Wang, R. Quantification of the effect of soil erosion factors on soil nutrients at a small watershed in the Loess Plateau, Northwest China. J. Soils Sediments 2020, 20, 745-755. [CrossRef]

43. Li, H.; Zhu, N.; Wang, S.; Gao, M.; Xia, L.; Kerr, P.G.; Wu, Y. Dual benefits of long-term ecological agricultural engineering: Mitigation of nutrient losses and improvement of soil quality. S. Total Environ. 2020, 721, 137848. [CrossRef] [PubMed]

44. Ma, J.; Chen, Y.; Wang, H.; Wang, H.; Wu, J.; Su, C.; Xu, C. Newly created farmland should be artificially ameliorated to sustain agricultural production on the Loess Plateau. Land Degrad. Dev. 2020, 31, 2565-2576. [CrossRef]

45. Gong, J.; Chen, L.; Fu, B.; Huang, Y.; Huang, Z.; Peng, H. Effect of land use on soil nutrients in the loess hilly area of the Loess Plateau, China. Land Degrad. Dev. 2006, 17, 453-465. [CrossRef]

46. D’Hose, T.; Cougnon, M.; De Vliegher, A.; Vandecasteele, B.; Viaene, N.; Cornelis, W.; Van Bockstaele, E.; Reheul, D. The positive relationship between soil quality and crop production: A case study on the effect of farm compost application. Appl. Soil Ecol. 2014, 75, 189-198. [CrossRef]

47. Jokela, W.; Posner, J.; Hedtcke, J.; Balser, T.; Read, H. Midwest Cropping System Effects on Soil Properties and on a Soil Quality Index. Agron. J. 2011, 103, 1552-1562. [CrossRef] 
48. Rotz, C.A.; Taube, F.; Russelle, M.P.; Oenema, J.; Sanderson, M.A.; Wachendorf, M. Whole-farm perspectives of nutrient flows in grassland agriculture. Crop Sci. 2005, 45, 2139-2159. [CrossRef]

49. Carmo, M.; García-Ruiz, R.; Ferreira, M.I.; Domingos, T. The N-P-K soil nutrient balance of Portuguese cropland in the 1950s: The transition from organic to chemical fertilization. Sci. Rep. 2017, 7, 1-14. [CrossRef] [PubMed]

50. Smith, K.A. Changing views of nitrous oxide emissions from agricultural soil: Key controlling processes and assessment at different spatial scales. Eur. J. Soil Sci. 2017, 68, 137-155. [CrossRef]

51. Tian, H.; Qiao, J.; Zhu, Y.; Jia, X.; Shao, M.A. Vertical distribution of soil available phosphorus and soil available potassium in the critical zone on the Loess Plateau, China. Sci. Rep. 2021, 11, 1-10. [CrossRef]

52. Wang, X.; Wang, G.; Tao Guo, T.; Xing, Y.; Mo, F.; Wang, H.; Fan, J.; Zhang, F. Effects of plastic mulch and nitrogen fertilizer on the soil microbial community, enzymatic activity, and yield performance in a dryland maize cropping system. Eur. J. Soil Sci. 2021, 72, 400-412. [CrossRef]

53. Manna, M.; Swarup, A.; Wanjari, R.; Ravankar, H.; Mishra, B.; Saha, M.; Singh, Y.; Sahi, D.; Sarap, P. Long-term effect of fertilizer and manure application on soil organic carbon storage, soil quality and yield sustainability under sub-humid and semi-arid tropical India. Field Crops Res. 2005, 93, 264-280. [CrossRef]

54. Wang, X.; Wang, N.; Xing, Y.; Yun, J.; Zhang, H. Effects of plastic mulching and basal nitrogen application depth on nitrogen use efficiency and yield in maize. Front. Plant Sci. 2018, 9, 1446. [CrossRef] [PubMed] 